\title{
Governance Impact Assessment on Large Infrastructure Project (LIP) Delivery
}

\author{
G. A. Zarewa ${ }^{1}$, A. D. Ibrahim ${ }^{2}$, Y. M. Ibrahim², and K. J. Adogbo ${ }^{3}$ \\ ${ }^{1}$ Lecturer, Department of Quantity Surveying, Bayero University, Kano, Nigeria, E-mail: galzarewa.qs@ buk.edu.ng \\ (corresponding author). \\ ${ }^{2}$ Professor, Department of Quantity Surveying, Ahmadu Bello University, Zaria, Nigeria. \\ ${ }^{3}$ Associate Professor, Department of Quantity Surveying, Ahmadu Bello University, Zaria, Nigeria.
}

Project Management

Received August 2, 2017; received revisions September 10, 2017; October 22, 2017; accepted October 23, 2017

Available online December 19, 2017

\begin{abstract}
The linkage of failures of many projects, including Large Infrastructure Projects (LIPs), to governance problems by previous studies implies that governance impacts projects' performance. Identification and understanding of the impacts have therefore become necessary in order to ensure that projects are governed in a way that will ensure their successful delivery. This study assessed impact of governance on delivery of Large Infrastructure Projects (LIPs) through a three phase research approach. The first phase involved literature review followed by semi-structured interviews with key stakeholders/role players in the governance of eight LIPs in different locations in Nigeria in the second phase. A thematic data analysis of the study's findings was finally conducted in the third phase to identify themes and sub-themes after which conclusions were drawn. The study established that governance impacts LIPs delivery both positively and negatively depending on how the governance is approached. Four LIPs were successful due to proper initiation, setting aside funds for the projects at the onset, proactive risk management, top management support, and simple governance policies and structures. Intuitive initiation on political exigencies, tying funding to erratic sources of funding without contingency arrangement, Procuring Authorities' (PAs) disregard for due process and consultants' advice, failure of a Procuring Authority (PA) to meet contractual obligations and change of government were identified by the study as major governance aspects that led to the abandonment of 4LIPs. The study concluded that there was a need for significant improvement and standardisation of approaches to governance of LIPs particularly in developing countries like Nigeria and accordingly recommends the development of a governance framework containing guidelines, including sanctions for violators, to guide the governance of the projects in the country.
\end{abstract}

Keywords: Governance, large infrastructure projects, and procuring authorities.

\section{Introduction}

The linkage of failures of many projects, including Large Infrastructure Projects (LIPs), to governance problems by previous studies implies that governance impacts projects' performance. Project Governance (PG) is primarily concerned with ensuring that projects are initiated, planned, executed and managed effectively and efficiently to achieve their intended objectives. Bourda (2011) was of the views that effective PG ensures that a project's objectives are aligned with those of its PA, the project is delivered efficiently, and supports means of exchanging timely, relevant and reliable information.

Identification of good governance as a critical success factor for implementing Public Private Partnerships (PPPs) projects by Almarri and Abu-Hijleh (2017) supports the views that governance impacts project delivery. Large Project Governance Research Project Report (2013) discovered that LIPs, which are important to society and its welfare, have failed partially or completely due to lack of appropriate governance. Investigations by Olusegun and Michael (2011) and Olalusi and Otunola (2012) into why projects continued to fail in Nigeria after over a decade of government's efforts to stem the tide identified governance and issues associated with it, as major causes of project failures and/or abandonment in the country. The foregoing revelations clearly show that governance of projects including LIPs impacts their delivery and necessitated the need to investigate how projects' delivery is governed with a view to understanding how the governance impacts their delivery.

It has however been observed that despite the identification of governance problems and issues associated with them as causes of projects failure and abandonment, not much efforts have been made to adequately address how governance impacts LIPs' delivery particularly in developing countries like Nigeria. This development resulted in a gap in literature related to governance of LIPs and its impacts on their delivery, 
which this study sets to address. Understanding the impacts will afford appropriate stakeholders an opportunity to identify and address causes of negative impacts that usually result in LIPs' failures and/or abandonment which are usually accompanied by loss of huge resources and employment opportunities. LIP in the context of this study refers to one single infrastructure project comprising of at least three sub-projects. LIPs include school complexes, hospitals, office complexes, factories, new trunk roads, airports, seaports, power stations, game reserves, etc. The study however recognises that fact since anecdotal evidence will not be enough to provide conclusive solutions to the research questions, empirical data is required to show, to a large extent, what stakeholders can do to ensure that LIPs are governed and delivered successfully.

\section{Literature Review}

\subsection{Governance}

Governance is a term often used to describe the processes and systems by which an organisation or society operates (Winch, 2001). It refers to the way in which an entity is managed at the highest level which involves allocation of authority, responsibility and accountability. There are essentially 2 types of governance that affect project delivery: Corporate Governance (CG) and Project Governance (PG). Corporate Governance (CG), which emerged from separation of management and ownership of enterprises due to growth and diversity in business, focuses on exercise of power in corporate entities (Clarke, 2008), provides structure for setting a company's objectives, means of attaining those objectives as well as monitoring the company's performance. $\mathrm{PG}$, on the other hand, provides a framework within which decisions for project development and implementation are made (Bekker and Steyn, 2009).

The role of governance in a project environment was highlighted by Nistor and Beleiu (2014) who opined that while choosing the right projects to implement corporate strategies is placed at the level of corporate governance (CG), the framework created by Project Governance (PG) supports effective implementation of the project. Impacts of governance on project delivery are usually the outcome of implementation of these roles in the project's delivery.

Robinson et al. (2010) identified six components of governance which include a simple organisational (governance) structure with clearly defined responsibilities and clarity between a person's role and their associated responsibilities in decision-making structure; strong leadership; good project management skills; good communication strategy and effective project controls and tools such as risks management systems as Critical Success Factors (CSFs) for delivering complex projects such as LIPs. This implies that the way these components are handled in the governance of a project, will also to a large extent, contribute in determining the impact governance will have on the project's delivery.

\subsection{Impact of Governance on Project Delivery}

The role of choosing the right projects to implement corporate strategies usually undertaken at the level of corporate governance (CG) which can be expatiated to include ensuring proper initiation processes, appointment of competent consultants and contractors, setting up an effective Governance Structure (GS), ensuring adequate and continuous funding, etc. can without doubt make or mar successful projects delivery. Previous studies have discovered many instances where projects succeeded or failed due to the ways these roles were undertaken. Brady and Davies (2013) linked the success of Heathrow Airport Terminal 5 and the London 2012 Olympic Park to, among other factors, the ways the two MIPs were governed. University Office Project Toolkit (2012) opined that it is important to get project initiation (which establishes the foundation of a project) right as it can make the difference between a successful and unsuccessful project. Poor decisions at early stages of a project were identified as governance challenge that may hamper the project's effective governance and successful delivery by Robinson et al. (2010). Appointment of consultants and contractors could make or mar successful project delivery because non-utilisation of competent consultants and contractors were identified among the factors that accounted for thousands of abandoned projects in Nigeria by Olalusi and Otunola (2012).

Other factors associated with governance that impact projects delivery include political support, political pressure, political interference, lack of continuity and inconsistency in policies and change in government. Many LIPs and other projects were known to be initiated, located or suspended due to political exigencies. Identification of political support as a critical success factor for implementing Public Private Partnerships (PPPs) projects by Almarri and Abu-Hijleh (2017) showed that political influence can impact project delivery. The same authors were of the views that politics might reduce the chances for success of a project by mobilising public against the project or by creating legislation capping service charges, adding more taxes, removing any tax relief, or stopping any subsidy support. A study by Damoah et al. (2015) ranked political interference third out of ten biggest causes of failure of government projects in Ghana. Zoufa and Ochieng (2014) discovered that when a new political party or government takes over, they end up discontinuing existing projects or just suffocating anyone they don't like'. The new governments in most scenarios abandon pervious government policies or programs with the hidden intention of embarking on selfconceptualised projects.

While the foregoing discourse highlighted impacts of governance on project delivery, a brief discussion on what constitutes a successful or failed project will make the outcome of the impacts clear.

\subsection{The Concept of Successful or Failed Project}

What constitutes a successful or failed project is not easy to define as there seem to be no general consensus on what a successful or failed project entails due to different value systems and cultures around the world. Evidence abounds that recognisingwhat constitutes success or failure in project management literature has remained vague (Ika, 2009). Attempts so far made to shed light on project success and failure by examining existing literature on the expectations and evaluations of success and failure clearly indicated that there are no common definitions of success or failure. Zoufa and Ochieng (2014) were of the view that an in-depth understanding of these terms will emerge from the activities undertaken during the lifecycle of specific projects under evaluation and based on stakeholder definitions, measurements and interpretations. 
Literature showed that the number of stakeholders that often interpret project success in different ways has recently increased (Mir and Pinnington, 2014). For instance, Lim and Mohamed (1999) defined project success by the use of micro and macro criteria. The micro criteria include time, cost, quality, performance and safety while the macro criteria comprised of the micro criteria as well as the project deliverables during the operational phase. Other dimensions to project success include customer satisfaction, business success generally in terms of profitability as well as those that consider accomplishing organisational objectives and customer satisfaction (Thomas and Fernandez, 2008). DruryGrogan (2014) underlined the difference between project success that refers to the achievement of the objectives and the project management success that in a traditional way refers to respecting the schedule, budget and specified requirements. Many authors were of the opinion that "golden triangle" was not enough to define project management success considering the variety of stakeholders, the importance of the context, the support from the sponsor or the top management, the relationship and communication with the clients (Drury-Grogan, 2014) and other essential factors. One of such authors, Bekker (2008) citing Cleland (1986) was of the view that project success was meaningful only if considered from two vantage points, that is, the degree to which a project was executed within budget, set time and to the desired quality; and the contributions made to the strategic goal of the project's client organisation.

Like project success, there is no general consensus on what constitutes project failure. From an elementary perspective, failure can be considered as lack of success or an inability to achieve success in an endeavour. Most frequently projects are considered failures when they fail to meet their targeted cost, time, or scope. However, Ika (2012) demonstrated that projects may be completed within their targeted time, cost and scope criteria but still be classified as failures thus making it necessary to consider failure beyond these criteria. Several researchers including Nelson (2005) supported this notion and equally criticised defining project failure by just using cost, time, scope and other traditional indicators; arguing that value added assessment criteria like project usefulness, value to organisations and learning potential must be considered when evaluating project failure.

The foregoing discussion on what constitutes a successful or failed project, which showed that project success or failure is simply matter of perception, have given an insight that could be used to assess the success or otherwise of LIPs even though the discussion showed that different scholars viewed project success or failure from different perspectives. Despite lack of consensus on what constitutes a successful or failed project, this study considers project success beyond the project's ability to meet on-time, within budget and quality requirements. The study concurs with Bekker (2008) who was of the view that project success was meaningful only if considered from two vantage points, that is, the degree to which a project was executed within budget, set time and to the desired quality; and the contributions made to the strategic goal of project's client organisation. On project failure, the study endorses the broad definition of project failure by Ika (2012) who was of the view that project failure exceeded the inability to meet stipulated schedules, cost and quality but also included its inability to achieve the functional requirements of projects as perceived by its relevant stakeholders.

The foregoing literature review has provided background information that can be used to address the study's research questions which include:

1. How is LIPs' delivery governed?

2. How does the governance impact the projects' delivery?

The theoretical framework of the study is based on the concept that good governance improves success rate of large infrastructure projects (Dunovic, 2010). The framework is underpinned by Garland's (2009) works which stated that PG helps to outline and understand relationship between all internal and external stakeholders involved in a project in addition to ensuring that appropriate structures are established to aid proper flow of information or reporting structure to permit informed decision making by projects' governing or steering boards. Findings by Klakegg et al. (2007) which stated that the key requirements of PG are to define how resources and risks are to be allocated among stakeholders as well as defining control measures for meeting set goals also underpinned the framework.

\section{Methodology}

The study was conducted through literature review and semi-structured interviews with key stakeholders/role players who participated in the governance of eight LIPs at various locations in Nigeria. The key stakeholders/role players were selected because they were considered to be in a position to provide relevant information for the study in line with the views of Oppong (2013) who opined that selecting subjects to take part in a research should be based on their ability to provide information considered relevant to the research problem. Their number was limited because it was not easy to come across experts that could provide data of sufficient quantity and quality, which will ensure that all important perceptions on the study area were uncovered. A study by Mason (2010) established that participants' expertise in a study topic reduces the number of participants needed in the study.

The eight sample LIPs (listed in Table 1) were purposively selected from 35 LIPs executed by State and Federal Government agencies and private sector entities, who are the major procurers of such projects, on the basis of their complexities, types, Procuring Authorities (PAs), size, sector and location. Choice of the samples on the basis of these characteristics was made with a view to understanding how the characteristics influence governance of the LIPs' delivery and subsequent impact of the governance on the projects' delivery.

Semi structured interview was used due the political, restricted and sensitive nature of the information required to address the study's research questions. Goodman (2008) argued that this type of interview assists in overcoming the problems of incomplete, restricted or often unavailability of data while Robert Wood Johnson Foundation (2008) opined that the method allows for specific issues to be addressed and encourages discussion of sensitive issues with interviewees. The interviews always started with introductory sessions followed by full 
explanation of purpose and relevance of the study to the respondents because Kumar (2011) discovered that respondents' understanding of purpose and relevance of a study determines and/or enhances quality of data. The interviewees were, thereafter, assured of protection of anonymity and confidentiality as well as stoppage of the interviews at their instances. Their consent on tape recording the interviews was also sought before the commencement of the interviews. Every effort including taking notes to avoid missing any details in the event of interruptions and ensuring that the interviewee and the interviewer were both actively involved in the discussion was made to ensure all responses were captured. Each interview took an average time of seventy minutes.

The interviews centered on four themes related to the sample LIPs' governance and delivery. Theme one involved questions on the LIPs' initiations, the processes followed in their initiations and how the initiation processes impacted their delivery. Theme two questions covered appointment of consultants and contractors and how the appointment impacted the LIPs' delivery. The third theme dealt with questions on PAs' attitude to due processes, established procedures and consultants' advice while the fourth one addressed components of the LIPs' governance identified as CSFs for delivering complex projects such as LIPs (governance policy/structure; project management; communication; delegation of responsibility, authority and accountability, etc.) and how they impacted the projects' delivery. Questions asked were as much as possible kept to minimum, simple, direct, clear, broad and open- ended while ambiguous, emotional, double-barreled, leading, loaded, and presuming ones were avoided in line with views of Harrell and Bradly
(2009) on the subject. Efforts were made to ensure that the respondents understood what they were asked while neutral language was used in order to prevent biasing the responses.

The study's interview analysis commenced with full and accurate transcription of the interviews with a view to enhancing quicker means of finding information, avoiding confusing who said what and forgetting important details. A summary of each interview containing the main expressed points, name or pseudonym of the interviewee and insights provided as suggested by Rubin and Rubin (2012) was made for the purpose of later referral. Concepts, themes, events were looked for, identified and marked while reading the transcripts.

The data was then coded and grouped into themes that reflected the study objectives for further analysis. The codes included words, phrases and/or sentences that reflected the meanings given to the various passages in the transcripts. Items that seemed to be essentially similar were assigned similar codes. Excerpts from across the interviews coded with the same labels were then sorted out; summarised and grouped together in order to see how each interviewee answered a particular question. The outcomes of the sorting, grouping and summaries were then categorised into themes for further analysis using thematic analysis which is a qualitative analytic method for identifying, analysing and reporting patterns (themes). The method according to Braun and Clarke (2006) minimally organises and describes data in rich detail in addition to interpreting various aspects of a research topic. The end results of the analysis were then used to draw conclusions. 
Table 1. List of the studied LIP sand interviewees

\begin{tabular}{|c|c|c|c|}
\hline $\mathrm{S} / \mathrm{N}$ & LIP Title & $\begin{array}{l}\text { Contract Sum at the } \\
\text { Time of Study }\end{array}$ & Role Players Interviewed \\
\hline A & $\begin{array}{l}\text { Construction of } 5 \mathrm{KM} \text { Asphaltic Dual Carriage } \\
\text { Way with Street Lights, etc. at the Headquarters } \\
\text { of all the Local Government Areas of a State in } \\
\text { North Western Region }\end{array}$ & Over N75.00 billion & $\begin{array}{l}\text { Managing Consultant and three } \\
\text { Contractors }\end{array}$ \\
\hline B & $\begin{array}{l}\text { Redevelopment of a Game Reserve for a State } \\
\text { Government in North Eastern Region of } \\
\text { Nigeria }\end{array}$ & Over N5.6 billion & Project Manager \\
\hline $\mathrm{C}$ & $\begin{array}{l}\text { Construction of a new Government House } \\
\text { complete with Infrastructure for a State } \\
\text { Government in North Western Region of } \\
\text { Nigeria }\end{array}$ & N8.0 billion & Project Manager \\
\hline $\mathrm{D}$ & $\begin{array}{l}\text { Establishment of a National Skill Acquisition } \\
\text { Centre for a Federal Government Agency in } \\
\text { South-South Region of Nigeria }\end{array}$ & Over N18.00 billion & Project Manager \\
\hline $\mathrm{E}$ & $\begin{array}{l}\text { Establishment of a National Petroleum College } \\
\text { for a Federal Government Agency in North } \\
\text { Western Region }\end{array}$ & Over N17.50 billion & Project Manager \\
\hline $\mathrm{F}$ & $\begin{array}{l}\text { Establishment of new University for a State } \\
\text { Government in North West Region of Nigeria }\end{array}$ & Over N8.00 billion & Project Manager \\
\hline $\mathrm{G}$ & $\begin{array}{l}\text { Construction of Head Office Complex for a } \\
\text { Media House in Kaduna }\end{array}$ & N1.234 billion & Project Manager \\
\hline $\mathrm{H}$ & $\begin{array}{l}\text { Establishment of } 3 \text { New Cities for a State } \\
\text { Government in North West Region of Nigeria }\end{array}$ & Over N30.50 billion & $\begin{array}{l}\text { Managing Consultant, Contractors } \\
\text { and PA's Representative on the LIP }\end{array}$ \\
\hline
\end{tabular}

Source: Interviews Findings (2014/2015/2016)

\section{Results and Discussions}

\subsection{Results}

Findings from interviews revealed that responses to similar questions on the four themes of the study differed from one LIP's participants to another on the basis of approaches to governance adapted by their respective PAs. A theme by theme findings are presented below.

\subsubsection{Governance of the LIPs initiations and its impacts on the projects' delivery}

Responses from interviewees indicated that setting up of committees to ensure successful take off and smooth delivery; preparation of LIPs' briefs in consultation with stakeholders including end users; affordability studies and setting aside funds for LIPs prior to their commencement; payment of compensation for land acquired before projects' takeoff and phasing of LIPs on the basis of priorities and and/or availability of resources; undertaken as part of the governance activities of the initiation phases of LIPs C, F, and G were discovered to have impacted the LIPs' delivery by ensuring their smooth take off and hitch free delivery. The projects, which were successfully completed, did not encounter any funding problem throughout their execution. A respondent from one of these LIPs said: There was smooth take off of the project because there was proper coordination between relevant parties. We never had problem of funding in this project. I'm sure they have set aside funds for the project. Another respondent described his experience thus: They financed it without going to the bank and I give them credit for that. They did their projection of income against expenditure and realised that they could finance it as a result of which they decided not to go to the bank to borrow. This decision worked well on both the sides of the client and the project.

Governance of the initiation phases of LIPs B, D, and Ewere described as satisfactory by respondents from the projects. The LIPs took off successfully and smoothly. The initiation of LIP B involved It entailed rigorous site visits and studies of similar international camps and wild life in South Africa. Cruger camp in South Africa was used as a case study to develop the project concept and a Feasibility Study. These efforts ensured successful take off and smooth delivery. The PM of the LIP said that "There was never a funding problem at the beginning due to the two-way funding arrangement made for the project." initiation of LIPs D and E was based on the outcome of needs assessment on which projects the PA should do for the benefit of the communities where the projects were eventually located after which the PA approached the state governments of the communities for pieces of land.

Inadequate governance of the initiation phases of LIPs $\mathrm{A}$ and $\mathrm{H}$ were, on the other hand, discovered to result in the abandonment of the projects. The projects were said to be initiated more on the basis on political exigencies rather than reality on the ground. A respondent was quoted as saying "I believed the LIPs were intuitively initiated to score political points". He wondered how a 
gigantic commercial project like LIP $\mathrm{H}$ was initiated without any form of feasibility study. The MC of LIP A said that "the government just decided to construct 5KM roads in each LGA. No feasibility studies or other analysis (processes) were undertaken before embarking on the project. I think it was initiated to open up the rural areas so as to improve their standard of living. Political considerations also played major role in the project's initiation".

The governance aspect of the LIPs' initiation faulted most by respondents from the projects, which led to their abandonment, was tying funding of the projects to erratic sources without any contingency arrangement. While LIP A's funding was solely tied to funds from Federation Account (which fluctuates most of the times), LIP H was expected to be funded by deposits from prospective buyers of the project's products once it reached $25 \%$ completion. Reduction in the amount being received from the Federation Account due to fall in oil price and failure to realise expected deposits made honouring of contractors' interim payments as at when due difficult for the PA. This development impacted negatively on the LIPs' delivery in terms of intermittent suspension of works and their subsequent abandonment. A major contractor on the project said that "They didn't do any funding arrangement. They only projected revenues from Federation Account and proceeds of the sale of government quarters (GPs) to pay for the works. Another respondent from LIP $\mathrm{H}$ described the funding problem as follows: "There is funding problem because it was envisaged that proceeds from the sale of the houses will begin to fund the project by the time it reaches $25 \%$ completion. This didn't happen due to the problem of marketability caused by the inadequate initiation processes mentioned before".

It can thus clearly be seen from the above findings that governance of the initiation phases of the LIPs impacted their delivery considerably as successes or failures of the LIPs could be traced to the way their initiation phases were governed.

\subsubsection{Appointment of consultants and contractors and its impacts on the projects' delivery}

Most of the consultants who were discovered to be appointed on the basis of their past performance performed reasonably well. MIPs A and $\mathrm{H}$ were the only projects that encountered projects design and management challenges due to failure of in-house staff to correctly design and effectively manage the projects. The challenge which caused delay and total review of the design was overcome by appointing MCs who took over the two responsibilities. The MCs' appointment, which angered the in-house staff, resulted in total review of the designs/estimates, delay in the execution of the projects and conflict between the MCs and the in-house staff with their attendant cost implications. Respondents from the MIPs who said the conflict hampered smooth governance and delivery of the MIPs advised Pas to always ensure that only competent personnel are assigned the responsibility of designing and managing MIPs and other projects. Appointment of contractors through nominations for all the MIPs except D and E and F created some challenges and made some respondents from the MIPs to allege that political considerations and corruption played some roles in the exercise. Some contractors for MIPs A and $\mathrm{H}$ failed to perform even after receiving advance payments while some contractors in MIP B could not even access advance payment made to them from banks without the help of consultants. Contractors in MIP C who were appointed without involving consultants refused to adhere to the consultants' instructions until the CEO of its PA threatened to revoke the contract of any contractor that failed to comply with the consultants' instructions.

Appointment of consultants and contractors for MIPs $\mathrm{D}$ and $\mathrm{E}$ in accordance with the provisions of Public Procurement Act, 2007 resulted in awarding contract for one of the projects to an incompetent contractor due to his lowest tender figure as result of which the project's PM recommended the review of the Act's provision on awarding contract to lowest bidder. Contractor selection process in LIP F was described as 'some sort of selective tendering' because a contractor handling other projects was said to be "just mobilised from another project to this one due to his long relationship with the client". There was no competition and consultants were not involved. The major contractor did not perform satisfactorily because he had so much work and overwhelmed. Results of the study also established that the use of a combination of PAs' in-house staff, some statutory agencies and Consultants to manage MIPs A, F and $\mathrm{H}$ caused conflicts, duplication of efforts and delay. Lack of clear demarcation of responsibilities between a consultant architect who started managing MIP F and MCs brought in to join the architect after the project has taken off resulted in conflict of authority between the two which hindered effective management of the project.

\subsubsection{PAs' attitude to due processes, established procedures and consultants advice}

Disregard for due process, procedures and consultants' advice by CEOs of the LIPs' PAs was another governance aspect that was discovered to have impacted the delivery of most of the projects. The MC of LIP A said that "some decisions taken by the consultants were at times over turned by either the executive council or the governor who happened to be an engineer. Some decisions were also at times taken by either the governor or the government before appropriate consultations. Both situations usually result in cost and time overruns". Issuance of direct instructions to contractors by Procuring Authorities of LIPs A, B, C, F and G and/or their representatives without recourse to consultants as required by due processes and procedures affected both the projects and contractors negatively in terms of cash flow and delays. The PM of LIP G reported that " $A$ contractor who tendered lowest price and also offered a discount was selected against our advice. We told them that the price was very low and not practical as well as cautioned them that the contractor may abandon the project towards the end. The contractor had cash flow problem as we predicted and stopped work after completing the carcass due to financial, managerial and ownership problems as a result of which the client had to, with the consent of the contractor, pay both the sub 
contractors and workers direct". A cost overrun of over N4billion (Four Billion Naira) and eighteen month time overrun were caused by indiscriminate instructions issued without recourse to due process and procedures by the CEO of PA of LIP H. The PM of LIP B identified change of government as the major governance challenge the project encountered that impacted negatively on its delivery and faulted the decision of the LIP's PA to commence the project few months to the end of its tenure. $\mathrm{He}$ attributed the LIP's failure to this factor because it was refusal of the new government to continue funding the project that led to its abandonment.

\subsubsection{Components of the LIPs' governance considered as CSFs for delivery of complex projects and their impacts on the projects' delivery}

The governance policies of the MIPs A, F and $\mathrm{H}$ which resulted in the establishment of complex Governing Structure (GS) made up of three government agencies each with its own governance structure and Managing Consultants (MCs) under the watch of the PA did not give decision making authority to any role player other than the Chief Executive Officers (CEO) of the PAs. The policy, described as cumbersome, made it mandatory for all issues requiring the attention of the PA to first be sent to the executing ministry (EM) who must in turn send it to the project monitoring directorate (PMD) for vetting and appropriate recommendations. Respondents from these project while agreeing that the policy and the GS at times served as risk and control measures complained bitterly that the policy posed caused duplication of efforts by MCs and SA, conflict between some role players, delayed decisions and suspension of works while waiting for decision by the CEOs. MIP B's governance policy resulted in a GS made up of consultants and contractors at the bottom who reported to and received instructions from the PM who in turn reported to an autonomous Task Force set up to govern the delivery of the project. No government agency apart from the PA's decision making organ was part of the MIP's GS. The policy made the Task Force accountable for the success of the MIP and granted it authority to approve project issues including payments without referring to the PA's CEO. Decisions in this MIP were said to be very fast and devoid of bureaucracy. Governance policies of MIPs C, D and E resulted in GSs described as simple and similar in outlook to that of MIP B but different in the parties therein. Government agencies which included Works or Physical Planning Departments of PAs and/or an executing ministry (EM) took the place of the autonomous task force but lacked most of the authorities the task force had in MIP B. The involvement of these agencies made decisions in the MIPs to be slower than in MIP B and this affected their effective delivery. GS of MIP G specifically designed to fast track the procurement of the MIP in view of the urgent need for its services enhanced its delivery. The governance policy of the MIP allowed the PM to refer issues to either the Board's Project Committee or Chairman Board of Directors of the PA or both depending on the issues involved. Decisions in this MIP were relatively faster than in MIPs $\mathrm{A}, \mathrm{F}$ and $\mathrm{H}$ but its use caused conflict and mistrust between the PM and Chairman Board's Project Committee. The governance policies of MIPs D, E, and G, which granted authorities to their PMs to approve changes without financial implications and those that can be contained within contingency provisions, were discovered to have minimised delays.

Results of the study also established that the use of a combination of PAs' in-house staff, some statutory agencies and Consultants to manage MIPs A, F and $\mathrm{H}$ caused conflicts, duplication of efforts and delay. Lack of clear demarcation of responsibilities between a consultant architect who started managing MIP $\mathrm{H}$ and MCs brought in to join the architect after the project has taken off resulted in conflict of authority between the two which hindered effective management of the project. Decision that made it mandatory for all correspondences and information from the PAs of MIPs D, E and F to any of the projects' participants and vice versa to be channeled through the PMs impacted positively on the projects' delivery. The adaption of a policy that barred all role players (including PAs and/or their representatives) except the PMs of the three projects from issuing direct instructions to either consultants or contractors also improved the effectiveness of the MIPs' management. Interference in the management of $\mathrm{A}, \mathrm{B}, \mathrm{C}, \mathrm{F}$ and $\mathrm{H}$ affected the effectiveness of the LIPs' management. The CEOs of the PAs on many occasions issued direct instructions to contractors which resulted in serious cost and time overruns. The communication systems of MIPs $\mathrm{A}, \mathrm{F}$ and $\mathrm{H}$ were described as cumbersome and uncoordinated by respondents from the projects. The systems, which lacked clearly defined communication made information to at times take considerable time before it reached its targeted recipient. Communication in MIPs B, C, D, E and $G$ which had simple GSs, coordinated approach in relaying information and clearly defined lines of communication impacted positively on the projects' delivery by enabling timely decisions and implementation of required actions, keeping relevant stakeholders informed on project issues and giving PMs some level of control. The use of both electronic and hard means of communication, that is, e-mails, telephone calls and letters in most of the LIPs fastened the rate of flow of information which in turn enhanced timely implementation of required actions. The interviews further revealed that stakeholder identification and engagement in most of the MIPs was limited to only stakeholders directly involved in the delivery of the projects even though problem with any stakeholder can derail a project. Governance challenges caused by noninvolvement of prospective end users of MIPs A, D and $\mathrm{H}$ in the projects' initiations have been discussed earlier.

The impacts created by these components of the LIPs governance on their delivery highlighted the fact that the approach adapted in a governing a project determines its success or failure.

\subsection{Discussions}

The foregoing discourse provided insight into governance of the LIPs and its impacts on their delivery. A theme by theme analysis and discussion of the study's findings are given below. 


\subsubsection{Governance of the LIPs initiations and its impacts on the projects' delivery}

Smooth take-off of three LIPs and their subsequent successful delivery due to the work of the committees set up to ensure their successful commencement and relatively faster decisions devoid of bureaucratic interference in the governance and delivery of one of the LIPs established the need for setting up steering committees with appropriate authority and accountability by PAs wishing to achieve hitch free delivery of their projects. This position is supported by findings of Lechler and Cohen (2009) which argued that steering committees, which could enfold many positive influences on project success, play an important role in the selection, initiation, definition, and control of projects. Development of LIPs' briefs in consultation with relevant stakeholders, which served the dual purposes of need assessment and business cases, resulted in the identification of the LIPs stakeholders; affording end users opportunity to make input on how they wanted the LIPs; minimsing changes, complaints from stakeholders and gaining their support; and identifying the resources need of the affected LIPs and expected risks. The positive impacts of these issues on the delivery of the LIPs clearly highlighted the importance of proper need assessment and business case to hitch free and successful delivery of projects in addition to affirming findings of previous studies on the subjects. Swanepoeland de Beer (2006) argued that participatory needs identification should be the first undertaking before a project commences. Bourda (2011) identified a compelling business case, stating the objectives of a project and specifying it's in-scope and out-of-scope aspects as a success factor for effective PG and successful project delivery.

Affordability studies by two PAs to determine whether they could comfortably afford to procure their LIPs or not and feasibility studies to determine the feasibility and viability of an LIP as part of the governance activities of the projects' initiation processes were clear cases of proactive risk management. The contribution made to the hitch free and/or successful completion of the affected LIPs by these measures suggested that proactive risk management contributes to successful project delivery thereby agreeing with the findings of Williams (2004) who discovered that proactive management of risks throughout a project's lifecycle is important for the project success. Other governance aspects of the LIPs' initiation processes that served the purpose of proactive risk management were setting aside funds for the procurement of some of the LIPs and payment of compensation for land acquired for some LIPs prior to their commencement with a view to avoiding occurrence of risks associated with the issues, particularly financial risks, and the likely challenges they may pose to the hitch free delivery of the affected LIPs. Paul and Ritche (2012) opined that financial risks associated with a project should be examined prior to the project's approval while Benta et al. (2011) argued that one of the key preliminaries to cope with the challenges of complex projects is proactive risk management. The proactive measures contributed to the hitch free delivery of the affected LIPs by preventing possible protest by land owners that could stall their progress and ensuring adequate and continuous funding which is a major requirement for successful project completion. Provision of adequate funds for projects based on proper feasibility studies prior to their commencement as a requirement for their success in Nigeria had earlier been recommended by Ubani and Ononuju (2013) after identifying undefined mode of financing and non compliance with agreed mode of payment as bane of project success in the country. Moreover, the Nigerian Public Procurement Act 2007 has, according to Zoufa and Ochieng (2014), highlighted that contracts should only be awarded if funds are available for them at the onset. Advance payment made to most of the contractors for the purpose of easy moblisatsion was discovered to have significantly contributed to timely and smooth mobilisation in addition to enhancing the contractors' working capital without resorting to unnecessary external borrowings. The gesture impacted the LIPs' delivery positively thereby affirming the positions of Rameezdeen et al. (2006) who posited that Mobilisation Advance Payment (MAP) is an interest free loan given by the client to reduces contractors' need for working capital, enhance contractors' working capital and motivate them to commence work at the earliest possible date. Phasing of an LIP on the basis of available resources, which helped in the successful completion of the project, clearly indicated the importance of commencing projects that a PAs' resources can procure successfully. This conclusion concurred with the provisions of the Nigerian Public Procurement Act 2007 requiring PAs to ensure that funds are available to meet obligations before formalising procurement proceedings.

Two of these LIPs failed due to their intuitive initiation more on the basis of political exigencies rather than economic and other realities on the ground. This inappropriate approach to initiation of the LIPs, which did not allow for proper need assessment and business case/feasibility studies, reinforced the views that initiation processes of a project can make or mar the success of a project as discussed earlier in this section. The impacts further highlighted the importance of project initiation on the basis of proper initiation processes rather than political exigencies. Swanepoel and De Beer (2006) argued that all community development projects should be built around community needs rather than political, departmental or individual needs. Protests by some direct beneficiaries who preferred other projects instead of the LIP being procured for them at the time and those who protested against the way one LIP was being executed indicated that proper needs assessments that involved the beneficiaries were not conducted before embarking on the LIPs and corroborated the findings of Swanepoel and De Beer (2006). The scholars discovered that for a project to be successful, the needs of the beneficiaries have to be clearly analysed and understood for appropriate planning to take place. This study is of the views that failure of communities to take ownership of and protect projects in their midst could be traced to non-consideration of their needs when initiating the projects.

Tying the funding of three LIPs to erratic sources of funds impacted their delivery negatively by failing to provide adequate and continuous funding to meet 
financial obligations as at when due. This failure, which led to the abandonment of the affected LIPs, was no longer news as many previous studies have identified it as a common cause of project failures not only in Nigeria but also in other African countries. Damoah et al. (2015) observed that many projects have been abandoned in developing countries due to lack of adequate funding and cited the example of the World Bank \$4.2 billion dollars Chad-Cameroon pipe-line project which failed due to funding problem. Olusegun and Michael (2011) identified inadequate funding and delayed payments among the major causes of projects failure in Nigeria. This study believes that tying funding of the LIPs that failed to erratic sources (Federation Account and deposits from prospective buyers) without any contingency arrangement was partly to blame for their failure

The foregoing analysis and discussions on the governance of LIPs' initiation phases and its impacts on their delivery clearly indicates that governance of the LIPs' initiation phases contributed immensely to the effectiveness or otherwise of their delivery as some of the factors that led to their successes and/or failures could be traced to how their initiation phases were governed. This development corroborated the views of University Office Project Toolkit (2012) which stated that it is important to get project initiation (which establishes the foundation of a project) right as it can make the difference between a successful and unsuccessful project.

\subsubsection{Appointment of consultants and contractors and its impacts on the projects' delivery}

Award of contracts to incompetent contractors due to political considerations and alleged corruption, which impacted the affected LIPs' delivery negatively, was not a new development in Nigeria as the Public Procurement Act, 2007, was according to Zoufa and Ochieng (2014), enacted to uphold transparency, prohibit nepotism and address other corrupt acts in the award of government contracts. Failure of contractors awarded contracts on the basis of lowest tender to perform efficiently affirmed the common saying that the lowest tenderer may not be the best and reaffirmed the findings of Alotaibi et al. (2016) which identified awarding contract to lowest bidder among major critical factors which contributed to delays in construction projects. Governance challenges encountered due to assignment of design and management of some LIPs to incompetent in-house staff and award of contract to incompetent contractors corroborated the findings of Olalusi and Otunola (2012) that identified non-utilisation of competent consultants and contractors among the factors that accounted for thousands of abandoned projects in Nigeria.

\subsubsection{PAs' attitude to due processes, established procedures and consultants advice}

The positive impact created by threat to revoke the contract of any contractor that failed to comply with consultants' instructions by the PA of one of the LIPs on the LIPs delivery clearly manifested the importance of top management support to consultants. Tukel and Rom (1995) in Patel and Robinson (2010) identified top management support for project managers to understand and achieve project objectives as the most critical success factor for successful completion of project. Cost and time overruns due to issuance of direct instructions to contractors by some PAs also corroborated the findings of Alotaibi et al. (2016) which identified changes by client among major critical factors which contributed to delays in construction projects. Unwarranted scope change and award of contract to contractor who later became bankrupt due to some Procuring Authorities' (PAs) disregard for due process and Consultants' advice were clear manifestations of impact of lack of top management support towards effective governance and delivery of the affected LIPs. Lack of top management support had earlier been identified as one of the causes of project failures in Nigeria by Akinyokun et al. (2009). Failure of one of the studied LIPs due to change of government could be partly attributed to its commencement at the tail end of the tenure of the government that initiated it without special arrangement to ensure its continuous funding whether the incumbent government was reelected or not. Extent literature on the subject of project failures due to change of government suggested that the issue was widespread in Africa. A survey conducted by Damoah et al. (2015) ranked change of government as the fourth major cause of project failures in Ghana while a Focus Group study by Zoufa and Ochieng (2014) blamed project failures in Nigeria on change of government. Olusegun and Michael (2011) advised governments to make efforts towards stopping abandonment of previously commenced project when there's change of administration.

\subsubsection{Components of the LIPs' governance considered as CSFs for delivery of complex}

\section{Projects and their Impacts on the Projects' Delivery}

Timelier decisions and minimum delays experienced in the delivery of LIPs with simple governance policies and structures affirmed the findings of Patel and Robinson (2010) who uncovered that simple PG allows for clear accountability and timely decision making. Faster decisions devoid of bureaucracy in the delivery of two LIPs due to their purpose made governance policies and structures affirmed the views of some authors on the subject. A GS reflective of a project's size and complexity should, according to Aon Enterprise Risks Governance and Management Practice (2011), be established at the initiation phase of a project. Garland (2009) opined that establishing a GS for an LIP that is independent of that of the LIP's PA reduces project decision nodes and facilitates faster and more qualitative decisions. Positive impacts created by effective communication on the delivery of some of the LIPs, which included enabling timely decisions and implementation of required actions, keeping relevant stakeholders informed on project issues and giving PMs some level of control, corroborated findings of many scholars on the subject. Clarke (1999) in Patel and Robinson (2010) identified good communication throughout a project as a key success factor while Robinson et al. (2010) mentioned good information strategy among critical success factors for delivering complex projects. Delegating decision making authority to role players other than CEOs in some LIPs, which fastened decision makings and helped in minimising 
delay in the delivery of the affected LIPs underscored the importance of delegating appropriate authority for all role players involved in the governance of a project. Stickney and Johnston (1983) believed that effective delegation and sharing of authority are vital prerequisites to successful management of a project and necessary condition for project success.

Failure to realise expected sales rate of products of an LIP due to incompatibility of the products' design with the culture of the buyers, refusal of members of a host community of an LIP to allow it to take off unless they were settled and protests by land owners for compensation, which hindered smooth delivery of the affected MIPs, could be traced to lack of an all-inclusive stakeholder identification consultation. Previous studies by Infrastructure Concession Regulatory Commission (2012) and Ibrahim et al. (2006) have identified refusal of some motorists to pay road tolls due to lack of stakeholder consultation at the early phases of Lekki Toll Road Concession Project and non involvement of host communities as risk associated with successful PPP projects in Nigeria respectively.

Delayed decisions with their attendant consequences on the LIPs discovered to be caused by inadequate and complex governance structures, use of one GS to govern LIP and its PA's other activities, ineffective communication systems and lack of authority for role players other than CEOs to take decisions in some LIPs corroborated findings of previous studies on causes of delays in PG and project delivery. Project Management Institute (2009) identified poor GS as a cause of ineffective PG while Garland (2009) discovered that using separate GSs to govern a project and other activities of the organisation procuring the project facilitates faster and more qualitative decisions. Cusack and Lo (2014) identified effective communication between project teams, top management and stakeholders as critical requirements for effective PG. Her Majesty's Treasury (2007) argued that it is unlikely to achieve effective PG without formal delegation of clear responsibilities, authority and accountability to role players. Conflict of authority between some role players due to lack of clear demarcation of responsibilities, authority and responsibility, which contributed to the failure of one of the LIPs, highlighted the need for PAs to always ensure that all role players in PG were assigned distinct roles that are clearly understood by each of them.

\section{Conclusions}

This study, which assessed impact of governance on LIPs' delivery, identified how major aspects of the LIPs' governance impacted their delivery. The rampant cases of project failures due to governance problems made the study relevant and necessitated the need for appropriate stakeholders to understand how current approaches to the governance of LIPs and other projects impact their delivery with a view to taking appropriate measures towards improving the projects' performance. Four LIPs were successful due to proper initiation, setting aside funds for the project at the onset, proactive risk management, top management support, and simple governance policies and structures. Improper LIPs initiation, tying funding of LIPs to erratic sources of funding without contingency arrangement, PAs' disregard for due process and consultants' advice, failure of a PA to meet contractual obligations and change of government were identified by the study as major governance aspects that led to the abandonment of 4LIPs. The study highlighted the need for significant improvement and standardisation of approaches to governance of LIPs in Nigeria. The development of a governance framework containing guidelines including sanctions for violators to guide governance of the projects in the country is accordingly recommended by the study.

It should however be noted that the study has some limitations which included the problem of generalisation due to small sample size (eight LIPs) and limited number of interviews conducted. The use of only semi-structured interview which is a qualitative method to conduct the study was another limitation that may be addressed by the use of quantitative or a combination of qualitative and quantitative methods to conduct future studies on the subject. While this study may not have offered conclusive answer to the question of LIPs' failure due to ineffective governance, its findings could, in spite of the limitations, serve as subjects for future studies.

\section{References}

Akinyokun, O. C., Angaye C. O., and Ubaru, M. O. (2009).Factor Analysis of the Performance Indices of ICTprojects in the Public Sector of Nigerian Economy.Journal of Technology Research, 1, 1-15.

Aon Enterprise Risks Governance and Management Practice (2011).Governance of Project Risks. A Guide for Non GovernmentalOrganisations. Aon Hong Kong Ltd.

Bekker, M. C. (2008). Project Governance for Large Capital Investments. A Thesis submitted to Graduate School of Technology Management, University of Pretoria, South Africa in partial fulfillment of the requirements for the Award of the Degree of Doctor of Philosophy.

Bekker, M. C. and Steyn, H. (2009).Project Governance: Definition and Framework.Journal of Contemporary Management, 6,214-228.

Benţa, D. Podean, L. M., and Mircean, C. (2011).On Best Practices for Risk Management in Complex Projects.InformaticaEconomică vol.15, no. 2/2011. Retrieved 8/7/2017 from revistaie.ase.ro/content/58/53-Benta,Podean.pdf

Bourda, F. H. (2011). Project Governance for Successful Projects.http://jindal.utdallas.edu/files/11/Bourdapaper.pdf of 1st June, 2013.

Brady, T. and Davies, A. (2013).Governing Complex Infrastructure Developments: Learning from Successful Projects.International Symposium for Next Generation Infrastructure, October 1-4 2013, Wollongong, Australia.

Braun, V. and Clarke, V. (2006).Using Thematic Analysis in Psychology.Qualitative Research in Psychology, 3, 77-101.

Clarke, A. (1999). "A Practical Use of Key Success Factors to Improve the Effectiveness of Project Management.International Journal of Project Management, 17(3), 139-145 
Clarke, T. (2008).Introduction: Theories of GovernanceReconceptualising Corporate Governance Theory after the Enron Experience. In T. Clarke (ed), Theories of Corporate Governance: The Philosophical Foundations of Corporate Governance. Routledge, London, United Kingdom.

Clealand, D. I. (1986). Measuring Success: The Owner's Viewpoint. Proceedings of the $18^{\text {th }}$ Annual Seminar/Syposium, Montreal Canada, Project Management Institute, 6-12.

Cusack, B. and Lo, S. (2014).Project Governance Requirements: A Case Study. Proceedings of Twenty Second European Conference on Information Systems, Tel Aviv 2014.

Damoah, S. K., Akwei, C., and Mouzughi, Y. (2015). Causes of government project failure in developing countries-Focus on Ghana.2015 Conference Proceedings, $f$ British Academy of Management. Accessed June, 20 2017 from: https://www.researchgate.net/publication/299537426_ Causes_of_government_project_failure_in_developin g_countries_-_Focus_on_Ghana

Drury-Grogan, M. L. (2014). Performance on Agile Teams: Relating Iteration Objectives and Critical Decisions to Project Management Success Factors, Information and Software Technology 56,506-515.

Dunovic, I. B. (2010). A Study of Project Governance Frameworks for Large Infrastructure Projects with Reflection on Road Transport Projects. International Journal of Organization, Technology and Management in Construction,2(1), 145-155.

Garland, R. (2009). Project Governance: A Practical Guide to Effective Project Decision Making. London, Kopanpage.

Goodman, J. L. (2008).Best Practices for Researching and Documenting Lessons Learned. United Space Alliance Houston, Texas. Retrieved December $6^{\text {th }}$ 2011 from klab.or/DE/lessons learned/reports/cr2008-214777.pdf.

Harrell, M. C. and Bradley, M. A. (2009).Data Collection Method: Semi-Structured Interviews and Focus Groups. RAND Corporation, 1776 Main Street, P.O. Box 2138, Santa Monica, CA 90407-2138, U.S.A.

Her Majesty's Treasury (2007). Project Governance: A Guidance Note for Public Sector Projects.HM Treasury, 1 Horse Guards Road. London SW1A 2HQ.

Ibrahim, A.D., Price A.D.F., and Dainty, A.R.J. (2006). An Analysis of Success Factors for PPP in Infrastructure Projects in Nigeria.Journal of Construction Management, 12(1), 2006.

Ika, L. A. (2009). Project Success as a Topic in Project Management Journals. Project Management Journal, 40(4), 6-19. http://dx.doi.org/ 10.1002/pmj.20137.

Ika, L. A. (2012). Project Management for Development in Africa: Why Projects are Failing and what can be Done about it. Project Management Journal, 43(4), 27-41. http://dx.doi.org/ 10.1002/pmj.21281.

Infrastructure Concession Regulatory Commission of Nigeria (ICRC, 2012).Public Private Partnership Manual for Nigeria.

Khalid, A. and Bassam, A. H. (2017). Critical Success Factors for Public Private Partnerships in the UAE Construction Industry A Comparative Analysis between the UAE and the UK. Journal of Engineering, Project, and Production Management, 2017,7(1), 21-32.

Klakegg, O. J., Williams, T., and Magnussan, O. M. (2007).Design of Innovative Governance Frameworks for Major Public Investment Projects: A Comparative Study of Governance Frameworks in UK and Norway.Research Conference: Projects in Innovation, Innovation in Projects.Brighton, CENTRIM, University of Brighton.

Large Projects Governance Research Project Report (2013). Designing Effective Governance Structure for Large Projects. Aalto University, 2013, Helsinki.

Kumar, R. (2011). Research Methodology: A Step-byStep-Guide for Beginners (Third Edition).SAGE Publications Ltd, 1 Oliver's Yard, 55 City Road, London EC1Y 1SP.

Laurie Williams (2004). Risk Management. Accessed $8 / 7 / 2017$

from

http://agile.csc.nesu.edu/SEMaterials/RiskManageme nt.pdf

Lechler, T. and Cohen, M. (2009). Exploring the Role of Steering Committees in Realizing Value from Project Management. Project Management Journal, 40(1), 42-54. doi: http://dx.doi.org/10.1002/pmj.20094

Lim, C. S. and Mohamed, M. Z. (1999).Criteria of Project Success: An Explanatory Reexamination.International Journal of Project Management, 17(4), 243-248. http://dx.doi.org/ 10.1016/S0263-7863(98)00040-4.

Mason, M. (2010). Sample Size and Saturation in Ph. D. Studies using Qualitative Interviews. FQS Forum: Qualitative Social Research, 11(3).

Mir, F. A. and Pinnington, A. H. (2014). Exploring the Value of Project Management: Linking Project Management Performance and Project Success. International Journal of Project Management,32, 202-217.

Nasser, O. A., Monty, S., and Chong, H. Y. (2016).Guidelines of Using Project Management Tools and Techniques to Mitigate Factors Causing Delays in Public Construction Projects in Kingdom of Saudi Arabia. Journal of Engineering, Project, and Production Management, 6(2), 90-103

Nistor, R. and Beleiu, I. (2014).Approaches Regarding the Dimensions of Project Governance. Proceedings of the $8^{\text {th }}$ International Management Conference: "Management Challenges for Sustainable Development, November $6^{\text {th }} 7^{\text {th }}$ 2014. Bucharest, Romania.

Olalusi, O. and Otunola, A. (2012). Abandonment of Building Projects in Nigeria-A Review of Causes and Solutions. International Conference on Chemical, Civil and Environmental Engineering (ICCEE 2012), March 24-25 Dubai.

Olusegun, A. E. and Michael, A. O. (2011).Abandonment of Construction Projects in Nigeria: Causes and Effects. Journal of Emerging Trends in Economics and Management Sciences (JETEMS) 2, 142 145.Scholarlink Research Institute Journals, 2011 (ISSN: 2141-7024).

Oppong, S. H. (2013) The Problem of Sampling in Qualitative Research-Retrieved from 
www.ajmse.leena-

luna.co.jp/AJMSEPDFs/Vol.../AJMSE2013(2.2-

21).pd...- $17^{\text {th }}$ May, 2014.

Patel, M. and Robinson, H. (2010). Impact of Governance on Project Delivery of Complex NHS PFI/PPP Schemes. Journal of Financial Management of Property and Construction, 15(3), 216-234.

Paul, N. and Ritche, M. (2012).Major Governance Toolkit-Overview and Guidance. Retrieved November 14, 2014 from http://www.ucisa.ac.uk/publications/major_project_go v.aspx

Project Management Institute (2009). A guide to the project management body of knowledge (4th Edition) (PMBOK® Guide).Project Management Institute, PA.

Rameezdeen, R., Palliyaguru, R. S., and Amaratunga, D. (2006). Financing Contractors in Developing Countries: Impact of Mobilization Advance Payment. Research Gate. Retrieved July 9, 2017 from https://www.researchgate.net/puglication/46481787_F inancing_contractors_in_....

Robert Wood Johnson Foundation (2008). Qualitative Research Guidelines Project. Princeton, NJ 08543.

Robinson, H., Carrillo, P., Anumba, C. J., and Patel, M. (2010).Governance and Knowledge Management for Public Private Partnerships. Wiley-Blackwell. West Sussex, PO1985Q, United Kingdom.

Rubin, H. J. and Rubin, I. S. (2012).Qualitative Interviewing: The Art of Hearing Data (Third Edition). Sage Publications Inc, 2455 Teller Road, Thousand Oaks, California 91320.

Stickney, F. A. and Johnston, W. R. (1983).Delegation and Sharing of Authority by the Project Manager. Project Management Quarterly, 14(1), 42-53.

Swanepoel, H. and De Beer, F. (2006).Community development. Breaking the cycle of poverty $4^{\text {th }}$ edition. Formeset Printers Cape. South Africa.

Thomas, G. and Fernandez, W. (2008). Success in IT projects: A Matter of efinition? International Journal ofProject Management, 26(7), 733-742. http://dx.doi.org/10.1016/j.ijproman.2008.06.003.

Tukel, O. I. and Rom, W. O. (1995).Analysis of the Characteristics of Projects in Diverse Industries. Working Paper, Cleveland State University, Cleveland, $\mathrm{OH}$.

Ubani, E. C. and Ononju, C. N. (2013).A Study of Failure and Abandonment of Public Sector-Driven Civil Engineering Projects in Nigeria: An Empirical Review. American Journal of Scientific and Industrial Research. ISSN:

2153-649X, doi:10.5251/ajsir.2013.4.1.75-82.

University Office Project Toolkit (2012).Project Initiation. University of Birmingham Intranet. Accessed 22 $2^{\text {nd }} \quad$ February 2016 from http//:intranet.birmingham.ac.uk/it/toolkit-project initiation-vi-August 2012.

Winch, G. M. (2001).Governing the Project Process: A Conceptual Framework. Construction Management and Economics, 19, 799-808.

Zuofa, T. and Ochieng, E. G. (2014).Project Failure: The Way Forward and Panacea for Development. International Journal of Business and Management,
9(11), 2014. Published by Canadian Center of Science and Education.

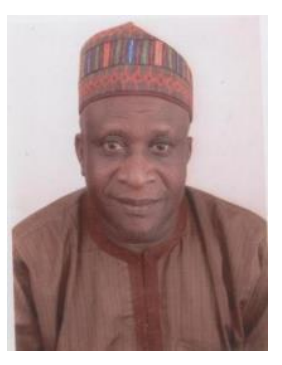

Dr. Gali A. Zarewa is a lecturer in the Department of Quantity Surveying, Bayero University, Kano, Nigeria. He holds BSc (Hons) in Quantity Surveying, MSc in Project Management and PhD in Quantity Surveying. His research interest areas include Quantity Surveying and Project Management, Knowledge Management, Construction Contract Administration and Project Governance. He is registered with Quantity Surveyors Registration Board of Nigeria (QSRBN) and Member, Nigerian Institute of Quantity Surveyors (MNIQS). Dr. Zarewa has worked for over thirty years in the public service before joining the academic community.

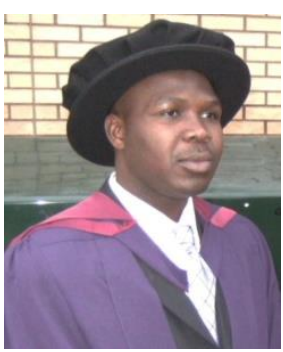

Ibrahim Ahmed Doko is a Professor of Quantity Surveying at Ahmadu Bello University, Zaria, Nigeria. He holds BSc (Hons) in Quantity Surveying, MSc in Construction Engineering \& Management and $\mathrm{PhD}$ in Construction Project Management. Professor Ahmed has research interest in the general areas of Quantity Surveying and Project Management with particular emphasis on Procurement, Cost Modelling, Public-Private Partnerships, Risk Management and Strategic Management of Construction firms. He is fully registered with Quantity Surveyors Registration Board of Nigeria, Fellow of the Nigerian Institute of Quantity Surveyors, Corporate Member of the Chartered Institute of Building UK, Full Member of the Nigerian Institute of Management (Chartered), Fellow of the Society for Construction Industry Arbitrators, Full Member of the Association for Project Management UK, etc. He has published 100+ academic papers in highly-rated international journals, conference proceedings and book chapters.

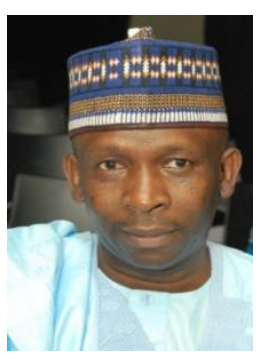

Ibrahim Yahaya Makarfi is a Professor of Quantity Surveying at Ahmadu Bello University, Zaria, Nigeria. $\mathrm{He}$ is a member of the Chartered Institute of Building (CIOB), The Association for Project Management (APM) and the Nigerian Institute of Quantity Surveyors (NIQS). His research interests are in Information Technology, Project Monitoring and Control and Strategic Management of Construction Firms. 
Dr. Kulomri Jipato Adogbo is an Associate Professor in the Department of Quantity Surveying, Ahmadu Bello University, Zaria, Nigeria. She holds a BSc (Hons) in Quantity Surveying, MSc in Construction Management and $\mathrm{PhD}$ in Quantity Surveying. She is a member of the Nigerian Institute of Quantity Surveyors and a Registered Quantity Surveyor. Dr. Adogbo has a very keen research interest in Gender studies, specifically 'Women in Construction' both as academics and professionals in the industry. Her interests also extend to the sustenance of the environment more specifically through studies relating to the use of local resources in construction, legal aspects of construction and financial accounting. 